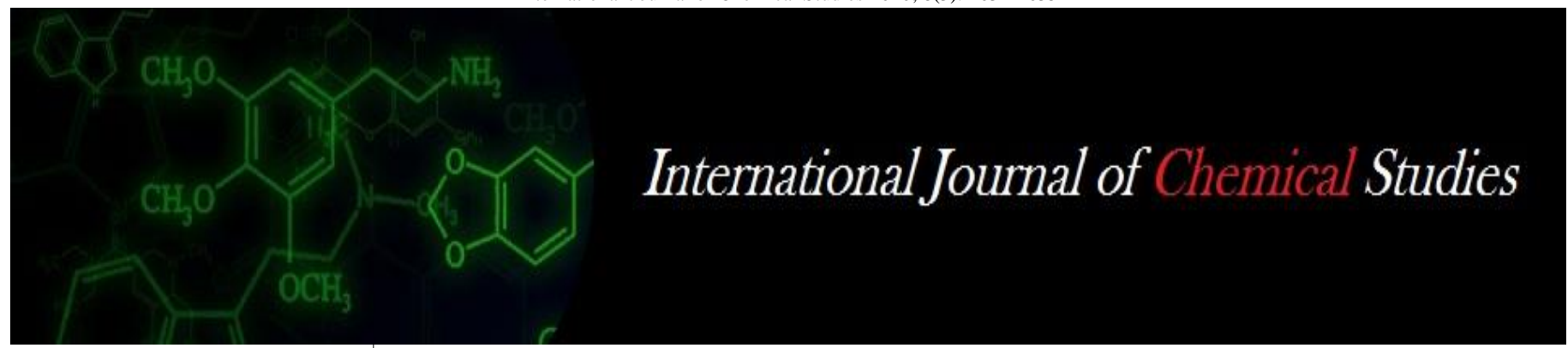

P-ISSN: 2349-8528

E-ISSN: 2321-4902

www.chemijournal.com

IJCS 2020; 8(3): 2632-2635

(C) 2020 IJCS

Received: 20-03-2020

Accepted: 24-04-2020

\section{Prodipto Sow}

Department of Soil Science and

Agricultural Chemistry, Institute of Agriculture (Palli Siksha

Bhavana), Visva-Bharati

University, Sriniketan, West

Bengal, India

Manik Chandra Kundu

Assistant Professor, Department of Soil Science and Agricultural

Chemistry, Institute of

Agriculture (Palli Siksha

Bhavana), Visva-Bharati

University, Sriniketan, West

Bengal, India
Corresponding Author: Manik Chandra Kundu Assistant Professor, Department of Soil Science and Agricultural Chemistry, Institute of Agriculture (Palli Siksha Bhavana), Visva-Bharati University, Sriniketan, West Bengal, India

\section{Difference in soil organic carbon content in various land uses and soil depths of lateritic belt of West Bengal}

\section{Prodipto Sow and Manik Chandra Kundu}

DOI: https://doi.org/10.22271/chemi.2020.v8.i3al.9611

\begin{abstract}
Soil organic carbon (SOC) is the key indicator of soil quality and overall sustainability of the environment. Information of $\mathrm{OC}$ in soil is very important as it influences chemical, physical and biological soil properties. In order to assess the difference in SOC content along depth and land uses and relationship of SOC with soil properties, a total of 54 soil samples were collected from 3 soil depths and 6 land uses of lateritic soil of Birbhum district of West Bengal. The soil physical properties like bulk density, particle density, sand, silt and clay content; chemical properties like $\mathrm{pH}, \mathrm{EC}, \mathrm{OC}$, available N, $\mathrm{P}_{2} \mathrm{O}_{5}, \mathrm{~K}_{2} \mathrm{O}$, S were estimated following standard procedure. Results exhibited significant variation of SOC with soil depths and land uses. There was decrease in SOC value with increase in soil depth for all studied land uses. The SOC value was highest and lowest forest and fallow land respectively for all the soil depths. Unrelatedly of soil depths, forest land and fallow land recorded highest and lowest SOC respectively. But, unrelatedly of land uses, $0-20 \mathrm{~cm}$ and $40-60 \mathrm{~cm}$ soil depth noted highest and lowest SOC respectively. The value of SOC due to combined effect of depth and land uses was noted highest and lowest in 0-20 cm depth of forest and 40-60 cm depth of orchard land respectively. The soil $\mathrm{pH}, \mathrm{BD}$, sand and silt content exhibited significant negative correlation with $\mathrm{SOC}$ and available $\mathrm{K}_{2} \mathrm{O}$ and $\mathrm{S}$ and clay disclosed significantly positive correlation with SOC.
\end{abstract}

Keywords: Lateritic soil, soil organic carbon, land uses, soil depth, soil properties

\section{Introduction}

Soil quality or soil health and overall sustainability of the environment is influenced by the soil organic carbon (SOC) content of soil (Lal, 2002) ${ }^{[12]}$. Information of SOC is very important as it has an impact not only on climate change but also on crop production by influencing chemical, physical and biological properties of soil. Soil has the capacity to store $\mathrm{C}$ two times more than atmosphere (Davidson et al., 2000) ${ }^{[7]}$. Variations in land uses and their management can influence the soil fertility by altering the content of SOC along soil depths (Meetei et al., 2020) ${ }^{[14]}$. Therefore, studies on SOC content with respect to land uses and soil depth is very essential for sustainable soil management. The soil of the lateritic belt of West Bengal, particularly of Birbhum district is usually poor in SOC and available nutrient status, sandy loam in texture, acidic in reaction (Manna et al., 2018) ${ }^{[13]}$. There are little evidences on depth-wise SOC content of various dominant land uses in the lateritic soil of Birbhum district of West Bengal. Thus, study on SOC content along depths and land uses as well its relations with soil properties was focused.

\section{Materials and Methods}

Depth-wise (0-20, 20-40 and 40-60 cm) representative soil samples were collected from forest land, orchard land, pasture land, cultivated rice land, cultivated rice-potato land and fallow land of lateritic soil of Birbhum district of West Bengal in 2017. Actually, a total of 54 soil samples [6 (land use types) X 3 (representative fields) X 3 (depths) = 54] were collected and processed for the analysis. For determination of bulk density (BD) separate core samples were taken from each soil depths. Oxidizable organic carbon content of soil was determined by chromic acid wet digestion method of Walkley and Black (1934) ${ }^{[19]}$ as described by Jackson (1973) ${ }^{[11]}$. Besides, soil properties like pH (Jackson, 1973) ${ }^{[11]}$, EC (Jackson, 1973) ${ }^{[11]}$, sand, slit and clay content (hydrometer method), BD by core method (Black and Hartge, 1986) ${ }^{[3]}$, 
density (PD) by pycnometer method (Black, 1965) [2], available $\mathrm{N}$ by alkaline permanganate method (Subbiah and Asija, 1956) ${ }^{[18]}$, available $\mathrm{P}_{2} \mathrm{O}_{5}$ by Bray's method (Bray and Kurtz, 1945) ${ }^{[4]}$, available $\mathrm{K}_{2} \mathrm{O}$ (Hanway and Heidel, 1952) ${ }^{[10]}$, available $\mathrm{CaCl}_{2}$ extractable $\mathrm{S}$ (Chesnin and Yein, 1950) ${ }^{[6]}$ were estimated to study the relation of SOC with them. The analysis of variance (ANOVA) of the effects of various land use types and soil depths on soil organic carbon (SOC) were tested by the procedure as described by Gomez and Gomez (1984) ${ }^{[9]}$. Simple Pearson's correlation analysis was done to estimate the relationship of SOC with soil properties using SPSS software (version 20).

\section{Results and Discussion \\ Effects of land uses and soil depths on soil organic carbon (SOC)}

Results showed significant depth-wise variations in SOC content in various land uses studied (Table 1, Fig. 1, Fig. 2). The highest and lowest SOC contents were observed in 0-20 $\mathrm{cm}$ and 40-60 $\mathrm{cm}$ soil depth of all the land use types studied. Thus, the SOC content was decreased with soil depth. However, the lowest values of SOC content of 40-60 $\mathrm{cm}$ soil depth was statistically at par with $20-40 \mathrm{~cm}$ soil depth except forest land.

Results also showed significant land use-wise variations in SOC content in various soil depths (Table 1, Fig. 1, Fig. 2). Comparison of SOC contents of $0-20 \mathrm{~cm}$ soil depth of all land uses exhibited its highest content in forest land $\left[5.72 \mathrm{~g} \mathrm{~kg}^{-1}\right]$, although statistically equal with orchard land [4.84 $\mathrm{g} \mathrm{kg}^{-1}$, and its lowest value in fallow land [3.65 $\left.\mathrm{g} \mathrm{kg}^{-1}\right]$, although statistically at parity with other land uses except forest land. Again, its value for $20-40 \mathrm{~cm}$ soil depth was highest in forest land $\left[4.50 \mathrm{~g} \mathrm{~kg}^{-1}\right]$ and was lowest in fallow land $\left[1.96 \mathrm{~g} \mathrm{~kg}^{-1}\right]$ which was, however, statistically at par with orchard land, pasture land and cultivated rice land. Comparison of SOC contents of 40-60 cm soil depth of all land uses exhibited its highest content in forest land $\left[3.47 \mathrm{~g} \mathrm{~kg}^{-1}\right]$, however, rest other land uses showed statistically equal amount of SOC.

Seeing the effect of land uses regardless of the effect of soil depths, it was perceived that average SOC content was highest and lowest in forest land $\left[4.56 \mathrm{~g} \mathrm{~kg}^{-1}\right]$ and fallow land [2.50 $\mathrm{g} \mathrm{kg}^{-1}$ ] respectively. However, such lowest value of fallow land showed statistically uniformity with cultivated rice land and pasture land (Table 1, Fig. 1, Fig. 2). Such higher value in forest land may be due to accumulation of residues of plant on forest soils as well as their limited disturbance. The anthropogenic factors like removal of plant residues from soil through crop harvest enhances the loss of organic matter by speeding up the oxidation, may be the one of the reasons for less SOC content in crop land. The relatively better organic matter content in the forest soil is attributable to higher biomass input. This indicates vegetation restoration has implication for improvement of soil nutrients. This result was in good agreement with Gebrelibanos and Mohammed (2013) ${ }^{[8]}$. Meetei et al. (2017) ${ }^{[15]}$ also documented that the SOC content of forest land recorded highest $\left(23.68 \mathrm{~g} \mathrm{~kg}^{-1}\right)$ and however, that of cultivated land recorded lowest $\left(13.13 \mathrm{~g} \mathrm{~kg}^{-1}\right)$.

Considering the main effects of soil depths (irrespective of land uses) it was observed that the mean soil organic carbon content was highest in surface $0-20 \mathrm{~cm}$ soil depth [4.05 $\mathrm{g} \mathrm{kg}^{-1}$ ] and lowest in 40-60 cm soil depth [2.13 $\left.\mathrm{g} \mathrm{kg}^{-1}\right]$. In general, it was observed that the soil organic carbon content was decreased with increase in soil depth (Table 1, Fig. 1, Fig. 2). This significantly higher quantity of organic $C$ in the surface soil might be due to highest root densities and increased biological activity (Nair and Chamuah, 1988) ${ }^{[16]}$. This result was in good agreement with Gebrelibanos and Mohammed (2013) ${ }^{[8]}$ and Meetei et al. (2017) ${ }^{[15]}$.

While studying the interaction effect of land uses and soil depth on SOC content, it was observed that the highest SOC content [5.72 $\left.\mathrm{g} \mathrm{kg}^{-1}\right]$ was recorded at the surface $0-20 \mathrm{~cm}$ soil depth of the forest land and the lowest $\left[1.83 \mathrm{~g} \mathrm{~kg}^{-1}\right]$ was obtained at 40-60 $\mathrm{cm}$ soil depth of the orchard land which was, however, statistically at par with $40-60 \mathrm{~cm}$ depth of fallow land, cultivated rice-potato land, cultivated rice land and pasture land; at par with $20-40 \mathrm{~cm}$ depth of fallow land, cultivated rice land, pasture land and orchard land as presented in Table 3 .

\section{Correlation of SOC with soil properties}

Simple Pearson's correlation studies between SOC and soil properties disclosed the significant negative relation with $\mathrm{pH}$ $(\mathrm{r}=-0.512, P \leq 0.01), \mathrm{BD}(\mathrm{r}=-0.953, P \leq 0.01)$, sand $(\mathrm{r}=-$ $0.577, P \leq 0.01)$ and silt $(\mathrm{r}=-0.500, P \leq 0.01)$ content of soil. However, SOC was significantly and positively correlated with available $\mathrm{K}_{2} \mathrm{O}(\mathrm{r}=0.706, P \leq 0.00)$, available $\mathrm{S}(\mathrm{r}=$ $0.479, P \leq 0.01)$ and clay $(\mathrm{r}=0.433, P \leq 0.01)$ content in soil. Meetei et al. (2020) ${ }^{[14]}$, however, reported that SOC of surface soil was significantly and positively correlated with available $\mathrm{N}$, available $\mathrm{P}_{2} \mathrm{O}_{5}$ and clay content and significantly and negatively correlated with bulk density. Similar significant positive correlation of SOC with available $\mathrm{K}_{2} \mathrm{O}$ was reported by Bertol et al. (2017) ${ }^{[1]}$ and that of SOC with available S was reported by Neptune et al. (1974) ${ }^{[17] .}$ Chaudhari et al. (2013) ${ }^{[5]}$ also reported that soil bulk density is negatively correlated with SOC.

Table 1: Depth-wise and land use-wise variations in mean organic carbon (OC) content of soil

\begin{tabular}{|c|c|c|c|c|c|c|c|c|}
\hline \multirow{2}{*}{ Depth of soil/ Land use } & \multicolumn{7}{|c|}{ Organic carbon content [g kg-1] } \\
\cline { 2 - 9 } & $\begin{array}{c}\text { Forest } \\
\text { land }\end{array}$ & $\begin{array}{c}\text { Orchard } \\
\text { land }\end{array}$ & $\begin{array}{c}\text { Pastur } \\
\text { e land }\end{array}$ & $\begin{array}{c}\text { Cultivated } \\
\text { land (rice) }\end{array}$ & $\begin{array}{c}\text { Cultivated land } \\
\text { (rice-potato) }\end{array}$ & $\begin{array}{c}\text { Fallow } \\
\text { land }\end{array}$ & $\begin{array}{c}\text { LSD } \\
(\mathbf{0 . 0 5})\end{array}$ & $\begin{array}{c}\text { Mean OC [LSD (0.05) }= \\
\mathbf{0 . 2 9}]\end{array}$ \\
\hline $0-20 \mathrm{~cm}$ & $5.72^{\mathrm{aA}}$ & $4.84^{\mathrm{aAB}}$ & $3.70^{\mathrm{aB}}$ & $4.02^{\mathrm{aB}}$ & $3.72^{\mathrm{aB}}$ & $3.65^{\mathrm{aB}}$ & 0.97 & $4.05^{\mathrm{a}}$ \\
\hline $20-40 \mathrm{~cm}$ & $4.50^{\mathrm{aA}}$ & $2.32^{\mathrm{bBC}}$ & $2.40^{\mathrm{bBC}}$ & $2.06^{\mathrm{bC}}$ & $3.02^{\mathrm{aB}}$ & $1.96^{\mathrm{bC}}$ & 0.72 & $2.57^{\mathrm{b}}$ \\
\hline $40-60 \mathrm{~cm}$ & $3.47^{\mathrm{bA}}$ & $1.83^{\mathrm{bB}}$ & $2.33^{\mathrm{bB}}$ & $1.87^{\mathrm{bB}}$ & $2.10^{\mathrm{bB}}$ & $1.91^{\mathrm{bB}}$ & 0.50 & $2.13^{\mathrm{c}}$ \\
\hline$L S D(0.05)$ & 1.25 & 0.95 & 0.47 & 0.20 & 0.97 & 0.79 & & \\
\hline Mean OC $[\mathrm{LSD}(0.05)=0.40]$ & $4.56^{\mathrm{A}}$ & $3.00^{\mathrm{B}}$ & $2.81^{\mathrm{BC}}$ & $2.65^{\mathrm{BC}}$ & $2.94^{\mathrm{B}}$ & $2.50^{\mathrm{C}}$ & & \\
\hline
\end{tabular}

Mean values in each column followed by different small letter(s) and mean values in each row followed by different capital letter(s) superscripted refers to significant differences in OC among different depth and land uses respectively at $p<0.05$. 
Table 2: Interaction effects of land use types and soil depth on organic carbon (OC)

\begin{tabular}{|c|c|c|c|}
\hline \multirow{2}{*}{ Land use types } & \multicolumn{3}{|c|}{ Organic carbon content $\left[\mathrm{g} \mathrm{kg}^{-1}\right]$ at various soil depth } \\
\hline & $0-20 \mathrm{~cm}$ & $20-40 \mathrm{~cm}$ & $40-60 \mathrm{~cm}$ \\
\hline Forest land & $5.72^{\mathrm{a}}$ & $4.50^{\mathrm{bc}}$ & $3.47^{\mathrm{cd}}$ \\
\hline Orchard land & $4.84^{\mathrm{b}}$ & $2.32^{\mathrm{de}}$ & $1.83^{\mathrm{e}}$ \\
\hline Pasture land & $3.70^{\mathrm{cd}}$ & $2.40^{\mathrm{de}}$ & $2.33^{\mathrm{de}}$ \\
\hline Cultivated land (Rice) & $4.02^{\mathrm{c}}$ & $2.06^{\mathrm{e}}$ & $1.87^{\mathrm{e}}$ \\
\hline Cultivated land (Rice-Potato) & $3.72^{\mathrm{cd}}$ & $3.02^{\mathrm{d}}$ & $2.10^{\mathrm{e}}$ \\
\hline Fallow land & $3.65^{\mathrm{cd}}$ & $1.96^{\mathrm{e}}$ & $1.91^{\mathrm{e}}$ \\
\hline LSD (0.05) & \multicolumn{3}{|c|}{0.70} \\
\hline
\end{tabular}

Interaction effects means of organic carbon of soil followed by the same small letter(s) are not significantly different from each other at $P \leq 0.05$

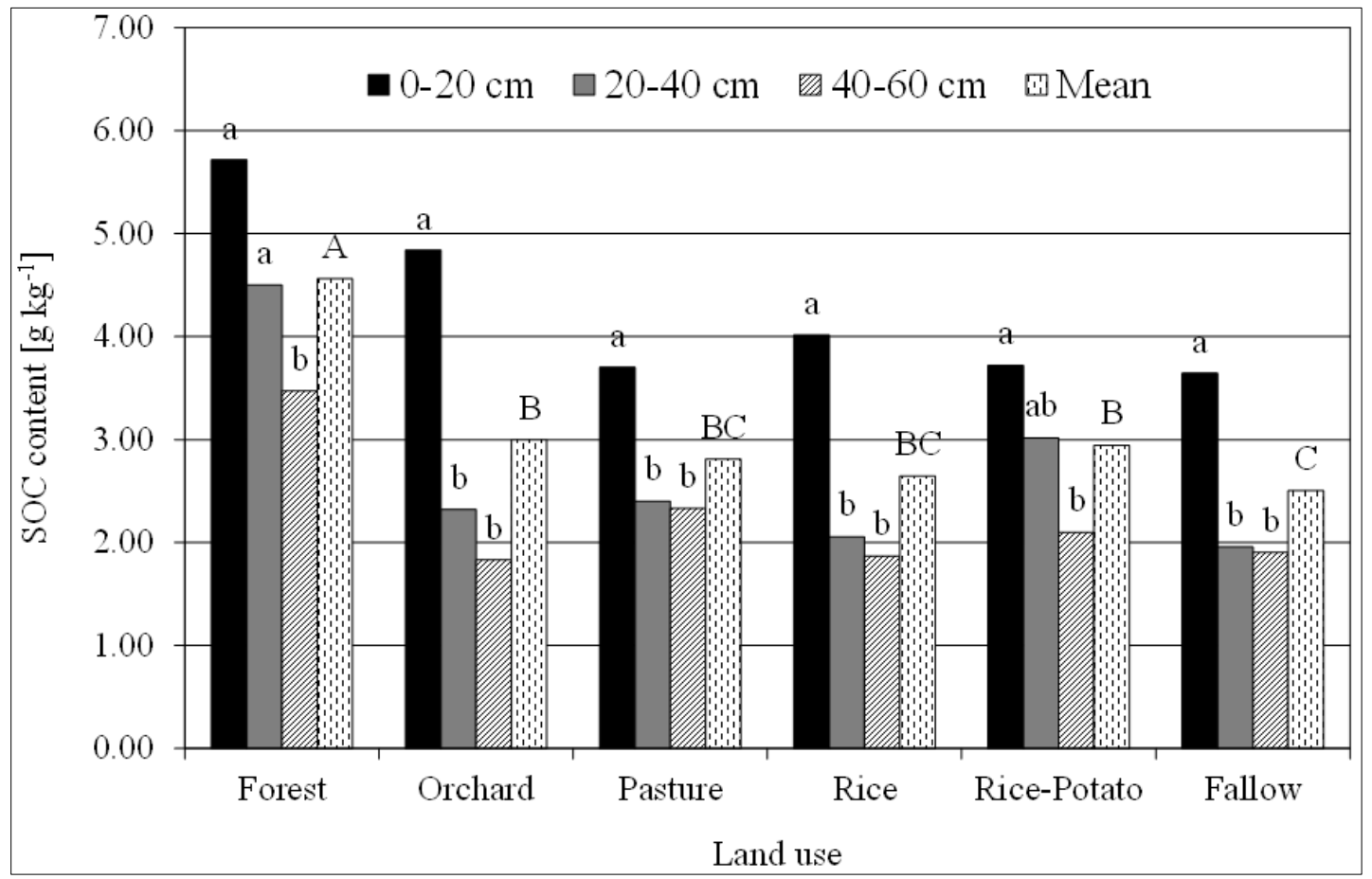

Fig 1: Depth-wise variation in soil organic C (SOC) content of soil in each land use [different small letters written at the top of the three columns of each land use indicates significant variation in SOC $(p<0.05)$; different capital letters written at the top of the six columns of all the land uses indicates significant variation in SOC $(p<0.05)]$.

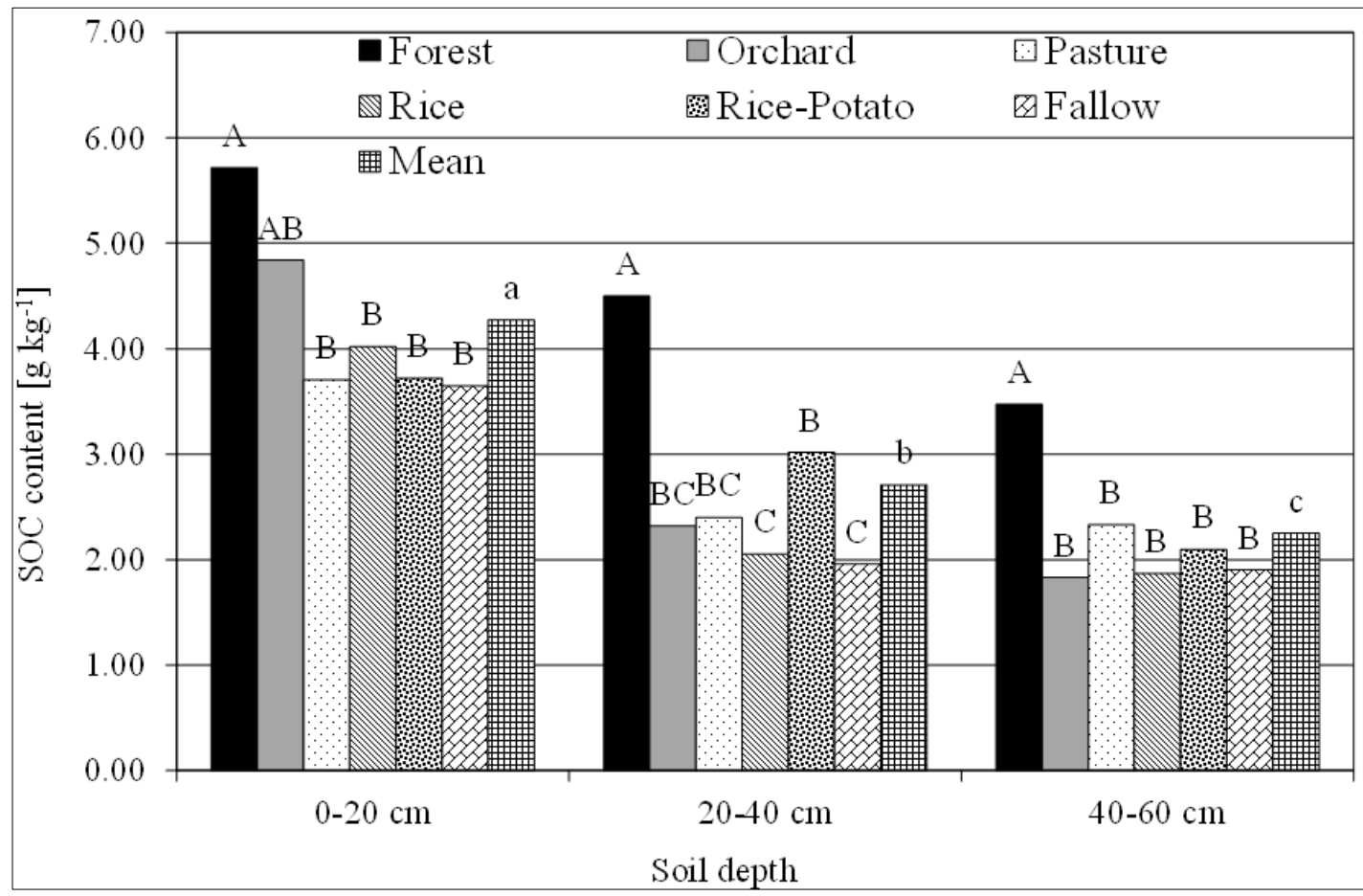

Fig 2: Land use-wise variation in soil organic C (SOC) of soil of three soil depths [different small letters written at the top of the six columns for each soil depth indicates significant variation in SOC $(p<0.05)$; and different capital letters written at the top of the three columns (for mean) indicates significant variation in SOC $(p<0.05)]$. 


\section{Conclusion}

Significant variation of SOC along depths and land uses was detected. In all the land uses, with increase in soil depth the content of SOC was lessened. The SOC content was highest in forest land and lowest in fallow land in all the land uses studied. The highest and lowest average SOC content was noted in forest land and fallow land respectively regardless of soil depths. Again, the highest and lowest average SOC content was noted in $0-20 \mathrm{~cm}$ and $40-60 \mathrm{~cm}$ soil depth respectively regardless of land uses. Combined effect of land uses and soil depth exhibited highest SOC in $0-20 \mathrm{~cm}$ soil depth of the forest land and lowest SOC in 40-60 cm depth of the orchard land. The SOC content was significantly negatively correlated with $\mathrm{pH}, \mathrm{BD}$, sand and silt content and significantly positively correlated with available $\mathrm{K}_{2} \mathrm{O}$ and $\mathrm{S}$ and clay content of soil.

\section{References}

1. Bertol I, Luciano RV, Bertol C, Bagio B. Nutrient and organic carbon losses, enrichment rate, and cost of water erosion. Rev Bras Cienc Solo. 2017; 41:e0160150.

2. Black CA. Methods of soil analysis. Part 2, 771. Madison, Wisconsin: American Society of Agronomy, 1965.

3. Blake GR, Hartge, KH. Bulk density. In: Klute, A., Ed., Methods of Soil Analysis, Part 1-Physical and Mineralogical Methods, 2nd Edition, Agronomy Monograph 9, American Society of Agronomy-Soil Science Society of America, Madison, 1986, 363-382.

4. Bray R, Kurtz LT. Determination of Total, Organic, and Available Forms of Phosphorus in Soils. Soil Sci. 1945; 59(1):39-46.

5. Chaudhari PR, Ahire DV, Ahire VD, Chakravarty M, Maity S. Soil bulk density as related to soil texture, organic matter content and available total nutrients of Coimbatore soil. Int. J. Sci. Res. Publ. 2013; 3(2):1-8.

6. Chesnin L, Yien $\mathrm{CH}$. Tubidimetric determination of available sulphate. Proc. Soil Sci. Soc. Am. 1950; 15:149-151.

7. Davidson EA, Trumbore SE, Amundson R. Soil warming and organic carbon content. Nature. 2000; 408(6814):789-790.

8. Gebrelibanos T, Mohammed A. Effects of slope aspect and vegetation types on selected soil properties in a dryland Hirmi watershed and adjacent agro-ecosystem, northern highlands of Ethiopia. African J. Ecol. 2013; 52(3):292-299.

9. Gomez KA, Gomez AA. Statistical Procedures for Agricultural Research. 2nd Edn., Int. Rice Res. Inst., John Willy and Sons, New York, Torento, Singapore, 1984, 643.

10. Hanway JJ, Heidel H. Soil analysis methods as used in Iowa state college soil testing laboratory. Iowa Agriculture, 1952.

11. Jackson ML. Soil Chemical Analysis. Prentice Hall of India Pvt. Ltd., New Delhi, 1973, 498.

12. Lal R. Soil carbon dynamics in cropland and rangeland. Environ. Pollut. 2002; 116(3):353-362.

13. Manna K, Kundu MC, Saha B, Ghosh, GK. Effect of nonwoven jute agrotextile mulch on soil health and productivity of broccoli (Brassica oleracea L.) in lateritic soil. Environ. Monit. Assess. 2018; 190:82, 1-10.

14. Meetei TT, Kundu MC, Devi YB. Long-term effect of rice-based cropping systems on pools of soil organic carbon in farmer's field in hilly agroecosystem of
Manipur, India. Environ. Monit. Assess. 2020; 192:209, $1-17$.

15. Meetei TT, Kundu MC, Devi YV, Kumari N. Soil Organic Carbon Pools as Affected by Land Use Types in Hilly Ecosystems of Manipur. Int. J. Bio-resource Stress Manage. 2017; 8(2):220-225.

16. Nair KM, Chamuah GS. Characteristics and classification of some pine forest soils of Meghalaya. J Indian Soc. Soil Sci. 1988; 36:142-145.

17. Neptune AML, Tabatabai MA, Han JJ. Sulfur Fraction Sand Carbon-Nitrogen -Phosphorus-Sulfur Relationships In: Some Brazilian And Iowa Soils. Journal Paper no. J7753 of the Iowa Agriculture and Home Economics Experiment Station. Project No, 1974, 1845.

18. Subbiah BV, Asija GL. A Rapid Procedure for the Estimation of Available Nitrogen in Soils. Curr. Sci. 1956; 25(8):259-260.

19. Walkley A, Black IA. An Examination of the Degtjareff Method for Determining Soil Organic Matter, and A Proposed Modification of the Chromic Acid Titration Method. Soil Sci. 1934; 37(1):29-38. 